\title{
Swedish Antiracism and White Melancholia: Racial Words in a Post-racial Society
}

\author{
byTobias Hübinette, Södertörn University and Multicultural Centre
}

\begin{abstract}
In recent years, a number of heated public debates have taken place in Sweden concerning the on-going use of racially and colonially marked words and expressions in everyday life and public discourse. As Swedish society views itself as, ostensibly, an antiracist and post-racial society, these debates raise uncomfortable questions regarding Swedish antiracism. This article looks at three examples of how the use of colonial and racial words and expressions is defended by predominantly white Swedes in the name of a Swedish antiracist exceptionalism which says that Sweden is a non-racist society, and which therefore means that words such as 'Oriental' and 'Negro' cannot be denigrating in a contemporary Swedish setting. The article argues that the general inability of institutions, media, academia, individuals and public discourse to take in and accommodate the histories and perspectives of minorities which are inscribed in such words is an expression of a white melancholia which harkens back to an imagined and idealised racially homogenous Sweden, when it was purportedly easier both to be a racist and an antiracist.
\end{abstract}

\section{Introduction}

During the time of high imperialism from the 19th to the first half of the 2oth centuries, an array of words, names, expressions and terms were used by the Europeans to describe and denote minorities both in the colonies and within Europe itself. Terms such as 'Negro', 'Redskin', 'Oriental', 'Eskimo', 'Lapp', 'Semite' and 'Gypsy' were used within the scientific world as well as by the state apparatus, by the media, in the cultural sphere and in daily life. However, after the Holocaust and since the accomplishment of formal decolonisation in the post-war period, the overt use of racial epithets and slang by state and media institutions and in social and public life has been contested by minorities and antiracists in several European and Anglophone countries in the Americas and Asia-Pacific. This political contestation over the language of race and racial discourse has manifested itself in a variety of ways ranging from the public pressure applied to professional North American sporting teams such as 'Redskins' to change their names and mascots, and the 2002 decision by the American House of Congress to replace the term 'Oriental' with the word 'Asian' in statistical and official documents (Han 2010; Kennedy 2003; Stapleton 2001). However, at the same time, this shift in public discourse about the acceptability of overtly racist language has taken place alongside a conservative backlash against so-called 'reverse racism' and 'political correctness' (PC) coming from the white majority population, and which often goes hand in hand with a nostalgic sentimentalisation of colonialism.

Public and media discussion of Europe's colonial and racist history has also recently generated controversy in Nordic countries such as Sweden. For example, a growing number of white Swedes have argued that the contemporary Swedish word 'neger' ('Negro'), and its various linguistic derivations, are not considered, for the most part, to be racist terms in public and media discourse, despite protestations from representatives from the African diaspora against the naturalized use of the word in media, academic, literary, artistic and political settings (Sabuni 2005). In 2009 a Swedish Facebook group called 'Det heter negerboll' ('The name is Negro ball') was able to recruit tens of thousands of white Swedes who defended the usage of the word 'neger' to reference a popular chocolate pastry, and in support of a white Swedish journalist who had defended the use of the term on public service television a month earlier. Another example of the politicization over language use can be seen within 
the biggest Asian studies department in Northern Europe, which bears the name the Department of Oriental languages, and is located at Stockholm University. Here, its senior staff members continue to use the term 'Oriental studies' and associated nomenclature such as 'Orient' and 'Orientals' even as junior members, particularly those who identify as Asian and having an Asian background, have protested against the continuing use of these terms (Hübinette 2002). Finally, in 2010, a German immigrant living in Sweden pointed out that a number of rock climbing tracks in Järfälla outside Stockholm have been named after terms associated with the Holocaust such as 'Zyklon B', 'Crematorium' and 'Crystal Night', and that these names had been used there for almost 20 years without significant protest. As with the Negro ball controversy, many Swedes defended the names as a reflection of a subcultural 'twinkle in the eye' type of humour that formed part of an essentially non-political jargon among rock climbers (Liljestrand 2010).

So how can we account for a growing public awareness of European colonial and racist history on the one hand, and such massive public resistance to criticism and the elimination of overtly racist slang and terms on the other? In this article, I try to understand this question in a Swedish contemporary context by placing these media debates over language and terminology into the context of contemporary Swedish race politics from a critical race and whiteness studies perspective.

\section{Swedish Whiteness}

Although critical race and whiteness studies does not exist as a coherent, accepted and institutionalized research field within Swedish and Nordic academia, where even the term 'race' is considered to be a taboo word, there are a few Swedish researchers who apply critical whiteness studies theories and perspectives to contemporary Swedish social and cultural conditions (Habel 2008; Lundstedt 2005; Lundström 2010; Mattsson 2006; Sawyer 2006; Pripp \& Öhlander 2008). The Swedish gender studies journal Tidskrift för genusvetenskap (Journal of Gender Studies) published a special issue on whiteness in 2010, and also worth mentioning here are a couple of studies examining Swedish everyday racism (Hällgren 2005; Hübinette \& Tigervall 2008, 2009; Kalonaityté, Kawesa and Tedros 2007; Lundström 2007; Motsieloa 2003; Schmauch 2006).

In order to make sense of this meagre output and the marginalization of Swedish critical race and whiteness studies, it is necessary to understand the historical construction and development of Swedish whiteness. The historical background to the construction of Swedish whiteness can be traced to the privileged position of the Swedes as constituting the 'whitest' of all white people (Hagerman 2006; Schough 2008). During the time of high imperialism, the Swedish academy also contributed substantially to race science. Swedish contributions to racial science include Carl Linnaeus' creation of the first modern scientific system for race classification in the mid-1700s, Anders Retzius' skull or cephalic index, which became one of the principal methods for race measurements, and the Swedish Institute for Race Biology, which was founded by the Swedish government in 1922 (Broberg 1995). The Swedish state also implemented a sterilization programme, underpinned by a racialised, heteronormative, gendered and classed eugenicist logic, which affected more than 60,000 Swedes before the programme was dissolved in the mid-1970s (Tydén 2000).

From the 1960s and 1970s, Sweden transformed its domestic policies and began to present itself internationally as a leading Western supporter of decolonization and anti-colonial, anti-segregation and anti-apartheid movements. The country became known internationally as the most radical Western proponent for social justice, antiracism and gender equality through Social Democratic-led multicultural and so-called state feminist policies. This change in governmental policy and rhetoric officially turned Sweden into a colour-blind society, and this new national self-image relegated racism to the historical past. The word 'race' became a taboo word itself, and in its national branding and identity formation through antiracism, which Sweden shares with other Nordic countries such as Norway, both national and international perceptions of Sweden as a left-liberal, antiracist and racially tolerant country were created 
and promulgated. It can be noted that Sweden, together with the other Scandinavian countries, has adopted the most children of colour from the former colonies in terms of international adoption rates (Selman 2002). This has, together with a previously generous refugee migration policy, created the perception of Sweden as a non-racist and post-racial country that has successfully 'dealt' with its racist and colonial past (Keskinen, Tuori, Irni and Mulinari 2009).

Recently, Swedish whiteness has also undergone a transformation in relation to Sweden's status as an immigrant country. While Sweden has always had an immigrant population and has always harboured ethnic, linguistic and religious minorities within its borders, the second half of the 1970s, and particularly the 1980 s onwards, saw non-white refugee immigration from, for example, Chile, Uganda and Vietnam take over from white labour immigration from neighbouring countries like Finland, Denmark and Norway and from European countries like Germany, Austria, Poland, Yugoslavia and Italy. Non-white immigrants from countries like Iraq, Iran, Turkey, Lebanon, Somalia, China and Ethiopia have dominated immigration to Sweden since the 1990s. In 2011, at least 10 per cent, or 970,000, of the total population of Sweden originate from non-European countries in Asia, Africa or South America according to Sweden Statistics (Hübinette 2012). This segment of the population is categorized in the public sphere as well as by political discourse as 'immigrant' or 'foreigner' (Pred 2000).

Even adopted and mixed Swedes of colour with a background from South America, Africa and Asia who, in spite of being more or less fully embedded within dominant Swedish identity in linguistic, religious and cultural terms, experience racist discrimination caused by their non-white bodies (Hübinette \& Tigervall 2009; Lundström 2010; Sawyer 2002). This specific development of Swedish whiteness has created a paradoxical situation and a self-image that race as a concept and as a category has been made completely irrelevant and obsolete in progressive, liberal, tolerant, antiracist and post-racial Sweden, while at the same time non-white Swedes are placed outside the category of Swede through words like 'immigrants'. It is this Swedish antiracism and Swedish whiteness that forms the contextual background to the following three debates.

\section{To Believe in the Orient}

Northern Europe's largest institution for Asian studies can be found at Stockholm University in the Department of Oriental Languages ('Institutionen för orientaliska språk'). The department houses teaching and research on West Asia and North Africa, Turkey and Central Asia, India and South Asia, and China, Japan and Korea. During high imperialism, the scientific name for Asian studies was Orientalism or Oriental Studies, and its practitioners were called Orientalists. At that time, in addition to being a geographically diffuse and almost imaginary place, the Orient was associated with decadence and despotism and 'Orientals' were stereotypically represented as being cunning, untrustworthy or even evil. However, this view of Asia and Asians has come under intense scrutiny within the Academy since the publication of Edward Said's Orientalism in 1978 (Macfie 2000). Said's book was a critique of the Western perception of and research on Asia and Asians, and, after Orientalism and the academic debate that followed, it has become almost impossible, particularly within the English speaking world, to use the terms 'Orient' and 'Orientals' without using quotation marks (Ahluwalia 2003; Hübinette 2003).

The debate concerning Orientalists and Oriental studies, however, has never really penetrated the Swedish Academy. Said's book was not translated into Swedish until 1993, and was then provided with an introductory chapter written by the Swedish Orientalist Sigrid Kahle (1993). In this chapter, Kahle outlined a defence of her Swedish Asian studies colleagues who, according to her, had not, unlike other Westerner scholars, been guilty of an Orientalising image of Asia and Asians. Kahle (1993, p. 49) wrote that concerning the post-war Swedish authors and scholars who had harboured an interest in Asia: 'This is a generation who stood on the side of the newly independent countries, and 
without doubt regarded these people as equivalent partners. This exceptionalist attitude towards former Swedish Asian studies scholars has been reiterated by other contemporary Asian studies researchers in Sweden (Enwall and Juntunen 1994).

Over the years to come, the name will no doubt be even more old-fashioned and obsolete. The department will also receive more and more students with an Asian background who have grown up in Sweden and who perceive concepts like the 'Orient' and 'Orientals' as not only outdated but also as offensive and derogatory. As a doctoral candidate, and together with other students and researchers, I attempted to change the name of the department to the Department of Asian Studies in 2002. The then head of the department and all the senior professors were, however, opposed to a name change. The head and the board of the department responded to the demand for a name change by explaining that terms like the 'Orient' and 'Orientals' do not reflect a colonial and racist attitude in a specifically contemporary Swedish academic context (Hübinette 2003). Northern Europe's largest institute for Asian studies thus showed that it had missed the last twenty years of debate on Europe's colonial past and its asymmetrical relationship towards Asia and Asians.

\section{The Beloved Swedish N-word}

The use of the Swedish word 'neger' is generally socially acceptable in everyday rhetoric and discourse alongside older European and domestic designations such as 'mor' ('Moor'), 'hottentott' ('Hottentot'), 'blåman' ('blue man') and 'svarting' ('darky') (Adelswärd 2009). Firstly, 'neger' is sometimes used by majority Swedes not only to describe Africans, but sometimes non-white people in general in for example everyday speech. Secondly, the word is sometimes also used in a 'positive' sense, as in children's songs and children's books, or to describe and celebrate black American musicians. For instance, this positive usage can be seen in the title of the white American journalist John Howard Griffin's book Black Like Me (1961), whose title was strangely enough translated in 1968 as 'Svart som en nigger' ('Black as a Nigger') (Griffin 1968).

Children's games such as 'Vem är rädd för svarte man?' ('Who is afraid of the black man?'), songs about 'negern' performed by popular artists like Evert Taube, Povel Ramel and Cornelis Vreeswijk, poems about 'negern' or even 'niggern' written by poets like Arthur Lundkvist, Gunnar Ekelöf and Jesper Svenbro, Pippi Longstocking's father 'Negerkungen' (the 'Negro king'), place names like 'Negerbyn' ('Negro village'), which can also be used as a nickname for specific neighbourhoods, nicknames such as 'NegerJohan' ('Negro-Johan') and 'Neger-Anna' ('Negro-Anna'), used to refer to adopted and mixed Swedes with African ancestry by their white relatives and friends, slang compositions as 'blåneger' ('blue Negro') and 'negerjobb' ('Negro job'), and established names in the world of chocolates and pastries such as 'negerkyss' ('Negro kiss') and 'negerboll' ('Negro ball'), both of which are still included in the Swedish Academy's Dictionary from 2006, all suggest and point to a long term everyday and normalized use of what can be understood as a specific Swedish version of the N-word (Sawyer 2001). It is here important to remember that the Swedish $\mathrm{N}$-word derives from another context than the English $\mathrm{N}$-word, and has, at least historically, meant both 'neger' and 'nigger', words which sometimes seem to have been used almost interchangeably. For many majority Swedes, the Swedish N-word has not been seen as demeaning and derogatory, and this is very much still the case although many would today avoid the word 'nigger', partly due to the arrival of African Americans and later on African migrants to Sweden who lately have politicized these words and questioned their usages. When I henceforth write the Swedish N-word, I am referring to the Swedish word 'neger'.

Furthermore, it was only in 2006 that the Swedish Academy, which sets the standard for the Swedish language, in the 13th edition of its highly respected dictionary, added the comment 'may be perceived as derogatory' after the entry for the word 'neger' (however in small print and in parenthesis) (Svenska akademien 2006). It was also in that same edition that the word 'chokladboll' ('chocolate ball') was introduced for the first time as a synonym to 'Negro ball'. This means that a high prestige national 
institution like the Swedish Academy, which also elects the Nobel prize in literature, only recently noticed (again in small print and in parenthesis) that the Swedish N-word may have a derogatory meaning at all. This indicates an institutional and national reluctance to problematize racist words and terms still in circulation in Sweden.

In the early twenty first century, a public debate regarding the word 'neger' arose due to the growing pressure of antiracist activism when a bakery had been reported to the National Ombudsman against Ethnic Discrimination (DO) on the basis of discrimination for displaying written signs selling 'negerbollar' ('Negro balls'). Even though the owner was never fined, other bakeries and cafés around the country began to showcase both 'Negro balls' and 'Negro kisses' in a sort of popular and defiant underdog-style civil disobedience campaign against the official complaint (Kidebäck 2004).

Concomitantly, it was reported in the media that official representatives, authorities and particularly police officers made use of the $\mathrm{N}$-word in official documents through wordings and phrases such as 'blåneger' ('blue Negro'), 'Oscar Negro' and 'Neger Niggerson' ('Negro Niggerson') in reports, inquiries and learning material (Klein 2009). As such, it is not just among ordinary citizens and owners of small enterprises that the $\mathrm{N}$-word is used, but also among representatives of the Swedish nation state.

I would argue that for many white Swedes, use of the $\mathrm{N}$-word has become something of a radical, 'anti$P C^{\prime}$ act of resistance. This is despite Sweden having an estimated population of 170,000 individuals with some form of African origin, including African slave descendants from the Americas and adopted and mixed Swedes (Hübinette 2012). In particular, members of these groups have repeatedly argued that the everyday use of the $\mathrm{N}$-word both hurts and is humiliating (Jonsson 2009; Sabuni 2005). This on-going debate about the use of the Swedish $\mathrm{N}$-word is most visible on Internet forums, but can also manifest itself in more unexpected places such as cultural and art institutions where, ostensibly, radical, antiracist and left-liberal writers, artists, actors, performers and musicians use the N-word explicitly in texts, novels, poems, exhibitions, movies, lyrics and on stage, in order to be seen as liberated and anti-bourgeois (Polite 2005).

The main, and almost the only, argument for the continuation of the use of the word expressed by Swedes who both belong to the majority and to minorities, as well as by Swedish institutions and authorities, is that the word forms part of a Swedish historical and cultural heritage and vocabulary and that it cannot be racist in a Swedish contemporary context. For example, the public agencies and government authorities who responded to criticisms of the neighbourhood name 'Negro' in the city of Karlstad in 2009 claimed that the place name's long history constitutes a part of Swedish cultural heritage. Agencies like the National Land Survey and the regional Värmland Museum argued that the place name should be understood as 'imaginative' and 'exotic' in a positive sense and something which cannot be seen as derogatory in a specifically contemporary Swedish context (Nilsson 2009). In other words, proponents of the word argue that discontinuing the word's use would to be to lose an 'authentic' and 'important' aspect of Swedish culture and, even more importantly, to admit that today's Sweden can be racist.

Thus, official Swedish institutions explicitly defend the continuous use of the N-word, for example as the name of a block in a Swedish city, as a way to preserve the cultural and historical heritage of Sweden. There is little understanding among many majority Swedes that the N-word can be demeaning and derogatory, exemplified by the statement of the National Land Survey: 'That many people would regard the name to be derogatory is not very likely' (Berglund 2009). As with the example of Stockholm University's Department of Oriental Studies, the underlying assumption is that Sweden is an antiracist, post-racial and non-racist country and that Sweden did not take part in the European colonial project. Therefore it is possible to use words like Oriental and the N-word in a contemporary Swedish setting as it cannot be negative within that setting - by contrast, it is viewed as positive. The same kind of perspective was also revealed when the Swedish Police Union explained in a 
statement after new revelations that the $\mathrm{N}$-word is used routinely by police officers on duty that police officers are now exposed to a 'value system panic' which can result in a situation similar to that of Communist Eastern Europe before 1989 and even a 'horror atmosphere' due to a fear of being reported for using purportedly derogatory names (Olsson 2010; Stiernstedt 2010). Again, what is at stake is the self-image of Sweden as a non-racist society and nation, and any attempt to claim that the $\mathrm{N}$-word might be offensive is therefore seen as an insult and, paradoxically, an attack on Swedishness itself.

In November 2008, the television programme leader Carin Hjulström defended in her talk show programme Carin 21:30, which airs on the public service channel SVT2, the continued use of the N-word in a discussion with the postcolonial author Jonas Hassen Khemiri. As this discussion took place, a dish of chocolate balls was displayed on the table in the studio. Hjulström said, among others, that she feels sorry for 'all children' who 'do not understand why you cannot say Negro ball', as opposed to those who feel that the word is offensive (Wirfält 2009).

The television programme generated a storm of sympathy on websites, blogs and discussion forums. The social media site Facebook was used to create a group calling itself 'The name is Negro ball, and it has always been called that'. In the presentation to the approximately 60,000 members of the group during the spring of $\mathbf{2 0 0 9}$ and before it was deleted by the end of the year by Facebook's headquarters in the US, the founders of the group again referred to the struggle to defend the Swedish cultural heritage.

The Facebook group declared the 11th of May to be 'Negro ball day' every year henceforth, and urged its members to visit the country's cafés, bakeries and pastry shops on that day to explicitly order a 'Negro ball'. At the same time, several antiracist groups protesting against the expression 'Negro ball' were launched, but none of the dozen or so antiracist Facebook groups reached over a thousand members. The group is, according to my interpretation, a good example of a popular 'anti-PC' uprising to defend the right to continue to say the $\mathrm{N}$-word in a contemporary Swedish setting, and in the end to continue to normalize and naturalize the denigration of minorities and to reinforce a racial hierarchy that privileges Swedisness as white.

Although the original Facebook group has been deleted, at the time of writing there are several similar groups. For instance, one group bears the name 'The name is Negro ball and it has always been known like that and it will always be known as that' and has around 60,000 members. Also at the time of writing, no antiracist Facebook group criticizing the continuous use of the Swedish $\mathrm{N}$-word has reached more than 1000 members. And finally, in December 2011 yet another Swedish N-word debate took place when the white gay icon, musician and multi entertainer Alexander Bard called an Ugandan actor and singer 'Negro' several times in a row ('neger, neger, neger') in a discussion about the word's racist meaning.

\section{Subcultural Anti-semitic Humour}

In the municipality of Järfälla outside Stockholm there is an ancient fortress situated on a rock that bears the name Gåseborg. Several climbing routes cross the rock, which according to the custom of the rock climbing community has been named by the first climber who created and marked out the trail. The trails at Gåseborg, some 40 in number, were created and named by various climbers between the years 19872001, and around 20 of them are named after historical events, phenomena and people associated with World War II. There are names such as 'Spitfire' and 'Stuka', but also a number of names that are directly associated with National Socialism and the Holocaust including 'Zyklon B', 'Himmler', 'Swastika', 'Crystal Night' and 'Crematorium'.

The routes have had these names for many years, they have been used on semi-official maps authorized by the municipality of Järfälla, and have seen hundreds of climbers navigate them (see for example http:// www.sverigeforaren.se/index.php/Gåseborg\#Ravinen). However, it was only in August 2010 that an immigrant with a German background criticized the names in the main Swedish morning paper Dagens 
Nyheter as trivialising the genocide of European Jews and exhibiting a lack of sensitivity for Holocaust victims (Liljestrand 2010). In the Dagens Nyheter article, one of the climbers who had named one of the tracks after Hitler defended this by saying that these type of names should be seen as an 'internal thing' among climbers (Liljestrand 2010). He added that he could not understand how they could be interpreted as disrespectful in a contemporary Swedish environment: 'I haven't thought about it very much, and I have not seen the names as disrespecting'. The story was picked up internationally and featured in North American, German, Austrian, British and Israeli newspapers, where it appeared that the international image of Sweden and the Swedes as an antiracist country created surprise or even shock because of the names of the routes (see for example Harman 2010).

An extensive internal debate on Internet forums like Bloxc (http://forum.bloxc.com) and 8a.nu (http:// www.8a.nu) was initiated among Swedish climbers, including some on international sites. A majority of the Swedes claimed in the debate that the Dagens Nyheter article was only an expression of 'PC hysteria'. Several climbers also linked it to the 'ridiculous' debate concerning the Swedish N-word, and it also emerged that there are apparently numerous routes around the country named in a similar spirit such as 'Bolted Negro' and 'Negro balls of steel'. Many of the writers had difficulties understanding why an irreverent attitude within a climbing subculture could be problematic to those outside it. Bloxc, the main forum for the Swedish rock climber community, even published a petition for free speech and introduced a competition, which the municipality of Järfälla encouraged, that involved devising a new name for Gåseborg. Some of the not so serious proposals included 'Hess against hate speech' and 'Klettern macht frei' ('Climbing is liberating') alluding to the Nazi concentration camp inscription 'Arbeit macht frei' and thereby again mocking the criticism by inventing even more derogatory names.

The climbing community of Sweden thus did not understand that someone could feel offended by such names, and still today maps mark the routes using the original names. Finally, as with the examples of Stockholm University and the Swedish N-word, it seemed to be impossible or unthinkable that the names could be humiliating and hurtful towards minorities in a Swedish contemporary context.

\section{Swedish Antiracism and White Melancholia}

The common thread between these three contemporary Swedish examples, although they originate from different spheres, is that they reflect the dominance of a certain Swedish attitude which sees itself as being antiracist. In Anglo-American critical whiteness research, the term hegemonic whiteness is sometimes used to explain the ways in which white people, despite differing social backgrounds and political views, can still share the same privileges and advantages, even including those who profess racist and antiracist views (Hughey 2010). Based on the three examples, a Swedish hegemonic whiteness is evident in the continuing use of racist words, expressions and terms despite attempts to criticize this speech as hurtful and demeaning towards minorities. The use of these kinds of racist and colonial words also points to a normalized and naturalized everyday racism in contemporary Swedish culture.

The main argument to defend the use of words like 'Oriental' and the N-word is that they cannot be perceived as racist when being used in a Swedish contemporary context. This line of argument reflects a self-image of Sweden as a country with no colonial history in Asia, no links to the slave trade and the plundering of Africa, and no historical links with Nazism and the Holocaust. The Sweden of today, as presented in dominant media and political discourse, is not a racist country, and does not have a racist culture and society, according to hegemonic Swedish whiteness.

At the same time, this specific Swedish 'antiracism', which refuses to acknowledge that racism exists in today's Sweden, is similar to the non-performative white anti-racism that Sara Ahmed (2004) has critiqued, in that it becomes a question of feeling good and moral. Such an attitude risks making invisible the negative effects of racist and colonial words upon minorities as it refuses to accept that 
such expressions can be hurtful and denigrating in a country which has already dealt with its racist past. Furthermore, the image of a post-racial state is not unique to Sweden, but what makes Sweden unique compared to other Western countries is its self-image of being the most antiracist and the least racist country in the world.

Another important ingredient of Swedish whiteness centres on the desire to remain neutral due to Sweden's long neutrality policy and to be able to feel good and moral and to be able to identify with the subordinate and the oppressed (Schough 2008). This Swedish historical exceptionalism and moral superiority can also be seen as a wilful forgetfulness grounded in a desire to deny responsibility for the fact that Sweden was and is a part of colonial European history and for not wanting to address the discrimination caused by the continued use of certain words and expressions that are loaded with Europe's racist history. Furthermore, many white Swedes' almost desperate disavowal to recognize that the Sweden of today is a country marked by racial diversity just like any other Western country, can also be explained by the self-image, mirrored by international perceptions of Sweden, that presents Sweden as a racially homogeneous country, where the Swedes are genetically and aesthetically the most valuable and beautiful of all white Western nations on earth (Hagerman 2006).

Similar to the postcolonial melancholia that British cultural studies scholar Paul Gilroy (2005) argues characterizes many British people who cannot accommodate the fact that Britain is no longer a world power, it is according to my analysis possible to talk about a white melancholy in Sweden. This white melancholia is caused by a mourning that the Swedish population is no longer as white as before. It also requires that the idealized phantasm of a homogeneous and white Sweden is maintained. But in order for the grief of racial decline to not become too overwhelming, it must manifest and articulate itself in a way so the white melancholic subject does not break apart completely.

Behind all the excited talk of a struggle for the freedom of speech, of a righteous rebellion against political correctness and of a heroic defence of the Swedish language and the Swedish heritage coming from many white Swedes in the debates, I find an anger directed towards Swedes of colour. This majority Swedish anger and also frustration is caused by them living permanently in the country and thereby destroying the love object of white Sweden. This anger over the fact that Sweden is a multiracial country today is expressed through the continuous use of colonial and racist words, expressions and jokes in the everyday life of Sweden. This means that for Swedish whiteness to continue to experience itself as being antiracist, and to stop the white melancholy from brimming over and exploding, a continuing denial that racism exists in today's Sweden is necessary. This results in an on-going disregard for the experiences and perspectives of minorities, and a continued lack of and absence of a postcolonial and antiracist ethic that would be necessary in the new racially diverse Sweden. The debate concerning the continuous use of colonial and racist words can in other words be seen as a site of struggle for what Swedishness means and should mean for the future .

Yet another example of this struggle is a public debate regarding a logo for a popular chocolate bar called 'Kina' ('China') which consists of a stereotypical caricature of an East Asian man. The debate took place in September 2011 and ended with a poll conducted by the public service company Swedish Television, which said that 97 per cent of the respondents did not agree that the logo could possibly be denigrating. I argue that on the one hand it is possible to say that 97 per cent of the Swedes see themselves as antiracists as they respond that this logo cannot be racist in a Swedish contemporary context as Sweden is a nonracist country. At the same time, by massively disavowing the possibility that such a stereotypical image can be racist, it is also on the other hand a reflection of a white Swedish culture and society that is as racist as any other Western country.

In this way, Swedish culture and society continues to pretend that Sweden is a country where only white Swedes live or should live. Through this white melancholia over the passing of a racially homogenous 
Sweden, many Swedes and Swedish institutions continue to disavow the fact that a new postcolonial Swedishness requires a reckoning with Sweden's colonial and racist heritage, and at the same time minorities are being discriminated against and their histories, experiences and perspectives are being silenced and made invisible in dominant representations of Swedish national identity. So to be able to once and for all transform today's excluding Swedishness, which does not allow non-whites to be Swedes, the discontinued use of racist and colonial words and expressions is required as a first step in enacting a postcolonial Sweden.

\section{References}

Adelswärd, V. (2009). Förtryck och Stolthet Ryms i Samma Ord [Oppression and pride in the same word]. Svenska Dagbladet. 24 January.

Ahluwalia, P. (2003). 'With Words We Govern Men': Orientalism and the Question of Translation. Stockholm Journal of East Asian Studies. 13, pp. 7-26.

Ahmed, S. (2004). Declarations of Whiteness: The Non-performativity of Anti-racism. Borderlands e-journal. 3(5): http://www.borderlands.net.au/vol5no3_2006/ahmed_nonperform.htm.

Berglund, C. (2009). Skamligt och Farligt [Shameful and Dangerous]. Värmlands Folkblad. 12 June.

Broberg, G. (1995). Statlig Rasforskning: En Historik över Rasbiologiska Institutet [State Race Research: A History of the Institute for Race Biology]. Stockholm: Natur \& Kultur.

Enwall, J. and Juntunen, M. (1994). Några Funderingar Kring Edward Saids Orientalism [Some Reflections Concerning Edward Said's Orientalism]. Orientaliska Studier. 82, pp. 3-8.

Gilroy, P. (2005). Postcolonial Melancholia. New York: Colombia University Press.

Griffin, J.H. (1968). Svart som en Nigger [Black as a Nigger]. Stockholm: Rabén \& Sjögren.

Habel, Y. (2008). Whiteness Swedish Style. Slut. 2, pp. 41-51.

Hagerman, M. (2006). Det Rena Landet: Om Konsten att Uppfinna Sina Förfäder [The Pure Country: On the Art of Inventing Ancestors]. Stockholm: Prisma.

Hällgren, C. (2005). 'Working Harder to be the Same': Everyday Racism among Young Men and Women in Sweden. Race, Ethnicity and Education. 8(3), pp. 319-342.

Han, J. (2010). Sen. Shin dedicated to making US Asians proud. Korea Times. 21 March.

Harman, D. (2010). Swedish Mountains Named 'Little Hitler' and '3rd Reich' Irk Some Climbers. Haaretz. 16 August.

Hübinette, T. (2002). Orientaler Finns Inte Längre [Orientals do not Exist Anymore]. Dagens Forskning. 1(1314), p. 54 .

Hübinette, T. (2003). Orientalism Past and Present: An Introduction to a Postcolonial Critique. Stockholm Journal of East Asian Studies. 13, pp. 73-80.

Hübinette, T. (2012). Den Svenska Utländsk Bakgrund-Befolkningen Den 31 December 2011 [The Swedish Foreign Background-Population December 31, 2011]. Botkyrka: Mångkulturellt Centrum.

Hübinette, T. and Tigervall, C. (2008). Adoption med Förhinder. Samtal med Adopterade och Adoptivföräldrar om Vardagsrasism och Etnisk Identitet [Adoption with Obstacles: Conversations with Adoptees and Adoptive Parents on Everyday Racism and Ethnic Identity]. Botkyrka: Mångkulturellt centrum.

Hübinette, T. and Tigervall, C. (2009). To be Non-white in a Colour-Blind Society: Conversations with Adoptees and Adoptive Parents in Sweden on Everyday Racism. Journal of Intercultural Studies. 30(4), pp. 335-353.

Hughey, M.W. (2010). The (Dis)Similarities of White Racial Identities: The Conceptual Framework of 'Hegemonic Whiteness'. Ethnic And Racial Studies. 33(8), pp. 1289-1309.

Jonsson, S. (2009). Nigger, Nogger och Neger: Varför Envisas Svenskar med Öknamnen? [Nigger, Nogger and Negro: Why do Swedes Stubbornly Use the Nicknames?]. Dagens Nyheter. 26 October.

Kahle, S. (1993). Orientalism i Sverige [Orientalism in Sweden]. Introduction in E. Said, Orientalism. Stockholm: Ordfront.

Kalonaityté, V., Kawesa, V. and Tedros, A. (2007). Att Färgas av Sverige: Upplevelser av Diskriminering och Rasism Bland Ungdomar med Afrikansk Bakgrund liSverige [To be Coloured by Sweden: Experiences of Discrimination and Racism among Youth with an African Background in Sweden]. Stockholm: Ombudsmannen mot etnisk diskriminering.

Kennedy, R. (2003). Nigger: The Strange Career of a Troublesome Word. New York: Vintage Books.

Keskinen, S., Tuori, S., Irni, S. and Mulinari, D. eds. (2009). Complying with Colonialism. Gender, Race and Ethnicity in the Nordic Region. Farnham: Ashgate.

Kidebäck, C. (2004). Negerboll Är Kränkande men Skånskt Konditori Slipper Skadestånd [Negro Ball Is 
Derogatory but the Scanian Café does not have to Fine]. Sydsvenska Dagbladet. 23 January.

Klein, E. (2009). Är Det Språkpoliser Vi Behöver? [Do we Need Language Policemen?]. Östgöta Correspondenten. 14 February.

Liljestrand, J. (2010). Nazistnamn på Klätterklippa iJärfälla [Nazi Names on a Climbing Cliff in Järfälla]. Dagens Nyheter. 12 August.

Lundstedt, A. (2005). Vit Governmentalitet. 'Invandrarkvinnor' och Textilhantverk: En Diskursanalys [White Governmentality. 'Immigrant Women' and Textile Handicraft: A Discourse Analysis]. Göteborg: Gothenburg University.

Lundström, C. (2007). Svenska Latinas. Ras, Klass och Kön i Svenskhetens Geografi [Swedish Latinas. Race, Class and Sex in the Geography of Swedishness]. Göteborg: Makadam.

Lundström, C. (2010). White Ethnography: (Un)Comfortable Conveniences and Shared Privileges in Field-Work with Swedish Migrant Women. Nordic Journal of Feminist and Gender Research. 18(2), pp. 70-87.

Macfie, A. L. ed. (2000). Orientalism: A Reader. New York: New York University Press.

Mattsson, K. (2006). Fröken Sverige i Folkhemmet: Ideal Svensk Kvinnlighet På 1950-Talet [Miss Sweden in the People's Home: Idealised Swedish Femininity in the 1950s]. In: Sandell, K. and Mulinari, D. eds. (2006). Feministiska Interventioner. Berättelser om och från En Annan Värld [Feminist Interventions: Stories on and from Another World]. Stockholm: Atlas.

Motsieloa, V. (2003). 'Det Måste Vara Någonting Annat'. En Studie om Barns Upplevelser av Rasism i Vardagen ['/t Must be Something Else'. A Study of Children's Experiences of Racism in Everyday Life]. Stockholm: Rädda barnen. Nilsson, D. N. (2009). Protester mot Kvartersnamnet 'Negern' [Protests against the Name of the Block 'Negro']. Aftonblade. 22 June.

Olsson, S. (2010). Polisfackets Brev [The Letter from the Policemen's Union]. Sydsvenska Dagbladet. 8 April. Polite, O. (2005). Vit Kvinna Pratar Svart med Vita Män [White Woman Speaks with White Men]. Dagens Nyheter. 23 April.

Pred, A. (2000). Even in Sweden: Racisms, Racialized Spaces, and the Popular Geographical Imagination. Berkeley: University of California Press.

Pripp, O. and Öhlander, M. (2008). Fallet Nogger Black: Antirasismens Gränser [The Case of Nogger Black: The Limits of Antiracism]. Stockholm: Agora.

Sabuni, N. (2005). Bli Kallad Neger Är Kränkande [To be Called Negro is Humiliating]. Aftonbladet. 31 August. Sandell, K. and Mulinari, D. eds. (2006). Feministiska Interventioner. Berättelser om och från En Annan Värld [Feminist Interventions: Stories on and from Another World]. Stockholm: Atlas.

Sawyer, L. (2001). Svartskallar, Negerbyar, och Andra Spöken i Den Svenska Vardagen [Black Skulls, Negro Villages and Other Ghosts in Swedish Everyday Life]. Invandrare \& Minoriteter. 28(1), pp. 25-26.

Sawyer, L. (2002). Routings: Race, African Diasporas, and Swedish Belonging. Transforming Anthropology. 11(1), pp. 13-35.

Sawyer, L. (2006). Makt, Vithet och Afrikansk Dans [Power, Whiteness and African Dance]. In: Sandell, K. and Mulinari, D. eds. (2006). Feministiska Interventioner. Berättelser om och från En Annan Värld [Feminist Interventions: Stories on and from Another World]. Stockholm: Atlas.

Schmauch, U. (2006). Den Osynliga Vardagsrasismens Realitet [The Reality of the Invisible Everyday Racism].

Umeå: Umeå University.

Schough, K. (2008). Hyperboré: Föreställningen om Sveriges Plats i Världen [Hyperborean: The Image of Sweden's Place in the World]. Stockholm: Carlsson.

Selman, Peter (2002). Intercountry Adoption in the New Millennium: The 'Quiet Migration' Revisited. Population Research and Policy Review. 21(3), pp. 205-222.

Stapleton, B. (2001). Redskins: Racial Slur or Symbol of Success? Bloomington: iUniverse.

Stiernstedt, J. (2010). 'Poliser Hämmas av Känsliga Ordval'. Dagens Nyheter. 8 April.

Svenska Akademien (2006). Svenska Akademiens Ordlista Över Svenska Språket [Swedish Academy's Dictionary of the Swedish Language]. Stockholm: Svenska Akademien.

Tydén, M. (2000). Från PolitikTill Praktik. De Svenska Steriliseringslagarna 1935-1975 [From PolicyTo Practice. The Swedish Sterilisation Laws 1935-1975]. Stockholm: Fritzes.

Wirfält, J. (2009). Facebook-Gruppen 'Det Heter Negerboll' Är Äcklig [The Facebook Group 'The Name is Negro Ball' is Disgusting]. Newsmill. 5 March. 